
\title{
R Research Square \\ Design of an industrial Photovoltaic-Driven Reverse Osmosis (PV-RO) Plant in Bahrain
}

\author{
University of Bahrain \\ Hanan Albuflasa \\ University of Bahrain

\section{Amin Sultan} \\ Aluminium Bahrain (ALBA)

\section{Philip Davies} \\ University of Birmingham
}

Ali Fardan ( $\square$ altajoor@gmail.com )

\section{Research Article}

Keywords: reverse osmosis, photovoltaic, renewables, energy, brackish water

Posted Date: February 16th, 2022

DOI: https://doi.org/10.21203/rs.3.rs-1286052/v1

License: (9) This work is licensed under a Creative Commons Attribution 4.0 International License. Read Full License 


\section{Abstract}

Renewable energy-driven desalination is a viable solution for such an energy-intensive industry. In the gulf cooperation council (GCC) region, where the largest desalination plants worldwide are accommodated, fossil fuels exhibit a real dilemma. Nonetheless, the region features an abundant solar energy resource.

This work contributes to the collective efforts for shifting the conventional fossil fuel-dependent desalination associated with a high carbon footprint toward an eco-friendly model by integrating photovoltaic (PV) technology.

Within this frame, an industrial brackish water reverse osmosis (BWRO) plant went under energy analysis to set the appropriate PV-driven RO design. Finally, a grid-connected design was simulated by Helioscope and PVsyst software to integrate half-cut cells PV modules $\left(460 \mathrm{~W}_{\mathrm{p}}\right)$ on the rooftops of three buildings.

The results showed that $525 \mathrm{~kW}$ AC power $(\mathrm{DC} / \mathrm{AC}$ ratio $\approx 1.2)$ could be achieved with a specific yield of $1258 \mathrm{kWh} / \mathrm{kW}_{\mathrm{p}}$, and an overall performance ratio of $79.1 \%$, representing around $786 \mathrm{MWh}$ annually.

\section{Introduction}

Brackish and seawater desalination are inevitable in arid regions lacking freshwater resources. However, the sustainability of the desalination industry has so many limitations, represented by the high energy consumption and dependence on fossil fuel power generation.

There are two main types of desalination technologies: thermal and membrane-based systems. Currently, reverse osmosis (RO) dominates non-thermal technologies worldwide; however, the energy consumption still represents around 50 to $60 \%$ of the total cost of water desalination (Zarzo \& Prats, 2018).

Therefore, many technologies have been developed to reduce the specific energy consumption (SEC in $\mathrm{kWh} / \mathrm{m}^{3}$ ), such as energy recovery devices (ERDs). These devices were introduced in the ' 80 s to exploit the energy of the pressurized brine to boost up the high-pressure pumps on the feed side of the RO plants. At present, the efficiency of these devices is approaching $97 \%$, leading to significant energy savings and lower SEC than the non-ERD RO configurations (Ahmed et al., 2019).

Nonetheless, sustainability is still questioned for the conventional desalination systems powered by fossil fuel. For that reason, associating renewable energy technologies to drive these systems provides an appealing solution (Ghaffour et al., 2015).

The combinations of renewable and desalination are quickly evolving and becoming economically and environmentally feasible. Solar, wind, wave, and geothermal sources, as well as fuel cell technology, could provide viable sources of energy to supply power for both seawater and brackish water desalination plants (Mahmoudi et al., 2017). 
At present, the PV-RO accounts for $43 \%$ of the total renewable energy-driven systems, emerging as the most superior and mature technology showing commercial feasibility with a life span of 20 to 30 years (Al-Karaghouli \& Kazmerski, 2013; Shatat et al., 2013).

Along with the PV-RO aided by the grid power, the stand-alone systems are still attracting attention for the remote areas, where the autonomous plants could be run unattended to overcome the freshwater availability and inaccessible electricity.

For instance, a brackish PV-RO plant with a capacity of $0.5 \mathrm{~m}^{3} /$ day was installed in a village located in northern Jordan, designed by Banat et al. (2012). The unit operated for $24 \mathrm{~h} /$ day with a daily energy demand of $7.754 \mathrm{kWh} /$ day obtained by 30 Polycrystalline Silicon PV modules having $54 \mathrm{~W}_{\mathrm{p}}$ capacity and two battery storage of $2760 \mathrm{Wh}$.

Alsheghri et al. (2015) designed a PV-RO system using RETScreen software to develop a full feasibility study. The aim was to build up a plant where the energy could be sold to the national grid of Abu Dhabi and concurrently supply the RO plant. The capacity of the RO plant was $200 \mathrm{~m}^{3} /$ day with an SEC of 6.99 $\mathrm{kWh} / \mathrm{m}^{3}$, while the total PV modules were 8000 of mono-Si-BP 590F, which has a capacity of $90 \mathrm{~W} / 0.63$ $\mathrm{m}^{2}$. The intermittent power generation was tackled by integrating the plant to the national grid, and the overall payback time was estimated at 23 years, with a benefit-cost ratio of 0.72 and a total reduction of GHG emissions of 1,035 tCO2 annually.

Likewise, in an Egyptian village on the coast of the red sea, an eco-friendly stand-alone SWRO plant was presented by Elmaadawy et al. (2020) to replace the one powered by a diesel generator. With a blend of renewable resources, multiple configurations were investigated for the optimal sizing based on technoenviro-economic aspects such as the total carbon emissions n, cost of energy, and net present cost. As a result, they found that the optimal configuration, which combines different renewable resources of the wind, solar, diesel Genset, and batteries storage, could reduce the net present cost and cost of energy by $60 \%$ and the total carbon emissions by $81 \%$.

The operational strategies of the small-scale brackish PV-RO plant were reviewed and discussed by Li et al. (2019) with elaborated guidance of each component, such as pumps, PVs, and membranes. They found that Silicon PVs are favored due to their robustness in combination with helical rotor pumps and brushless DC motors to enable a life expectancy of 20 years.

To avoid the intermittent power supply and maintain the steady-state operation, the grid-connected PV-RO is favorable and more economical since the steady-state operation of RO depends on the stable flow and pressure to maintain the product water quality and reduce membrane fouling (Freire-Gormaly \& Bilton, 2018, 2019; Mito et al., 2019).

Ghenai et al. (2018) assessed grid-tied and off-grid systems to find a hybrid power supply optimal for the SWRO plant in Sharjah. The grid-tied system comprising PV, inverters, and grids offers superior benefits to 
the off-grid one containing PV, inverter, diesel generator, and battery banks in terms of the low cost of energy, high sellback of excess electricity, and low $\mathrm{CO}_{2}$ emissions.

Rahimi et al. (2021) did a feasibility study of PV-RO with a capacity of $2000 \mathrm{~m}^{3} / \mathrm{d}$ based on different structures of grid-tied combinations. The plant located in the southern coastal areas of Iran enjoys 2900 $\mathrm{h}$ of sunshine and an annual irradiance of about $2200 \mathrm{kWh} / \mathrm{m}^{2} / \mathrm{d}$.

The technical assessment has also investigated the types of membranes to demonstrate the most economically viable scenario with the lowest unit production cost and shortest payback period, which was the grid-connected scenario rather than the off-grid one.

Karavas et al. (2019) provide a techno-economical assessment of the optimal configurations of an experimental PV-RO located in Greece, producing water at the rate of $150 \mathrm{l} / \mathrm{h}$. They have explored five different scenarios of the autonomous operation mode under energy storage, variable load, and energy management systems. The optimum configuration was the energy management system introduced with artificial intelligence based on fuzzy logic and cognitive maps, which exhibit the lowest production cost and power losses.

In the same context, Gulf Cooperation Council (GCC) countries have limited freshwater resources and natural endowments, making them fall into the water-stressed and severely water-scarce nations (AlZubari et al., 2017; Dawoud, 2005).

Around $99 \%$ of potable water is supplied through desalination of seawater as a key source, and secondly is the depleted underground water, which has high salinity and degraded quality (Saif et al., 2014).

Furthermore, the water consumption in GCC was rapidly increasing with around $140 \%$ growth in the demand within the last decade and is subjected to increase substantially due to high population growth, urbanization, and industrial developments (Pirani \& Arafat, 2016).

Globally, the desalination industry of GCC accounts for $57 \%$ of the overall production capacity, and it accommodates $55 \%$ of the entire world's desalination plants (Saif, 2012; Shomar \& Hawari, 2017).

It is necessary to shift the GCC economic model, which relies on unsustainable fossil fuels, toward more diversified energy sources and enter the renewables era.

The enormous potential of renewable energy has not yet been utilized in GCC, particularly the solar energy that irradiated the area with about 500-600 W/m² (W. E. Alnaser \& Alnaser, 2011).

Although, there are some initiatives in the Arabian Gulf in this field. The United Arab Emirates has established a green city called Masdar, which depends totally on renewable energy and acts as a carbonfree zone in Abu Dhabi. Moreover, a solar power station with a capacity of $100 \mathrm{MW}$ is under construction, namely Shams 1 (W. E. Alnaser \& Alnaser, 2011). 
In Dubai, the largest solar park will cover an area of $48 \mathrm{Km}^{2}$ to generate $1 \mathrm{GW}$ using Photovoltaic (PV) and Concentrated Solar Power (CSP) through 2030, and many other projects are planned in KSA, Oman \& Kuwait.

In the case of Bahrain, a single solar PV project held by Bahrain Petroleum Company (BAPCO) was established to generate $5 \mathrm{MW}$ in 2014. Likewise, the University of Bahrain, EWA, and BAPCO conducted solar and wind projects for power generation.

One of the private projects is the Bahrain World Trade Center, constructed with three wind turbines, each having $0.66 \mathrm{MW}$ capacity, covering around $11-15 \%$ of the tower's energy demand (W. Alnaser \& Alnaser, 2009).

Recently, on national levels, EWA has promoted PV solar cells to public set up these types of systems at homes and offered multiple plans for financial support.

Ambitiously, Bahrain is planning to get $5-7 \%$ of the total generated power from renewables by 2025 , and so the other GCC members like Kuwait and UAE who have already committed to diversifying their energy mix with renewables (Abdmouleh et al., 2015; Munawwar \& Ghedira, 2014).

Nevertheless, few of these projects were designed to be integrated with desalination units; however, KSA is planning to establish two PV \& wind farm desalination plants in the future (Atalay et al., 2017).

Early studies in Bahrain went back to Al-Qahtani (1996) experimental design of lab-scale PV-RO to determine the energy production profile of the solar panels over one year (1994). Another study was conducted by Lindemann (2004), who investigated two systems powered by wind and solar energy. He investigated the design of the PV system to desalinate seawater having 42,000 mg/l TDS, with a production capacity of $800 \mathrm{l} /$ day, to identify the right operational strategies that could reduce the SEC.

Since then, PV-RO has not been part of any study in Bahrain. However, this study proposed a design for grid-connected PV-RO for an industrial brackish water RO plant (BWRO) as a part of the collective efforts for shifting the fossil fuel-dependent industry into the green zone.

\section{Methods And Data}

The grid-connected PV-solar system is supposed to supply the RO plant; therefore, when there are enough solar irradiations, the PV arrays will supply the plant; otherwise, it will inject the power into the grid. On the other hand, in the case of inadequate power from the PV arrays, the grid will offset the energy required to run the plant, Fig. 1.

To identify the sizing of the PV system, the first step involves an energy inventory on the whole RO plant containing the units of pretreatment, RO modules, and post-treatment, Fig. 2. 
The TDS of the brackish water is around 12,000 mg/l which contains around $3 \mathrm{mg} / \mathrm{l}$ of hydrogen sulfide. Therefore, the pretreatment stage contains the degassing unit to remove hydrogen sulfide $\left(\mathrm{H}_{2} \mathrm{~S}\right)$.

The $\mathrm{H}_{2} \mathrm{~S}$-free water is subjected to the multimedia and cartridge filters to remove the suspended solids. This phase includes a dosing system of sulfuric acid, chlorine, sodium metabisulfite, and the antiscalant.

The RO contains 126 seawater modules placed into two stages (TM820C-400 SWRO class). The first stage has twelve pressure vessels (PV), each consisting of seven elements, while the second has six PVs, each containing seven elements.

The plant has a recovery rate of $75 \%$ and a production capacity of $107 \mathrm{~m}^{3} / \mathrm{h}$. A high-pressure pump with a nominal pressure of 30 bar is integrated into the first stage, while a booster pump is connected to the second stage to push the pressure up to around 40 bar. The post-treatment of the RO product is mainly pertaining to the remineralization and disinfection dosing systems.

\subsection{PV system design and simulation}

The assessment of solar resources for the relevant location was obtained using two different simulation software of PV-Syst and Helioscope. The BWRO plant is located at a latitude of $26.08762^{\circ} \mathrm{N}$ and a longitude of $50.6103^{\circ} \mathrm{E}$.

The irradiance data have been retrieved from the PVGIS (Photovoltaic Geographic Information System), integrated with the PVsyst software.

The rooftops of four different buildings located in the same zone, including the BWRO plant building, were selected, Fig. 3.

The rooftop dimensions were calculated using Helioscope's tool of field segmentation. Then, the building heights and all rooftop tilts were measured locally using laser distance meters.

PV arrays were selected from the category of the half-cut cell having a nominal capacity of $460 \mathrm{~W}_{\mathrm{p}}$ and made of mono-crystalline cells, Table (1).

\section{Table (1)}

\section{The PV module specs at Standard Test Conditions (STC)}

Temperature of $25^{\circ} \mathrm{C}$ and an irradiance of $1000 \mathrm{~W} / \mathrm{m}^{2}$ 


\begin{tabular}{|ll|}
\hline Module type & LR4-72HPH-460M \\
\hline Manufacturer & Longi Solar \\
\hline Maximum Power $\left(\mathrm{P}_{\max }\right)$ & $460.0 \mathrm{~W}$ \\
\hline Technology & Si-Mono $(144(6 \times 24)$ cells $)$ \\
\hline Weight & $23.3 \mathrm{~kg}$ \\
\hline Voltage at Maximum Power $\left(\mathrm{V}_{\mathrm{mp}}\right)$ & $41.900 \mathrm{~V}$ \\
\hline Open Circuit Voltage $\left(\mathrm{V}_{\mathrm{OC}}\right)$ & $49.700 \mathrm{~V}$ \\
\hline Short Circuit Current $\left(\mathrm{I}_{\mathrm{SC}}\right)$ & $11.730 \mathrm{~A}$ \\
\hline Current at Maximum Power $\left(\mathrm{I}_{\mathrm{mp}}\right)$ & $10.980 \mathrm{~A}$ \\
\hline Dimensions & $2094 \times 1038 \times 35 \mathrm{~mm}$ \\
\hline Operational Temperature & $-40 \sim+85^{\circ} \mathrm{C}$ \\
\hline Temperature Coefficient $\left(\mathrm{P}_{\max }\right)$ & $-0.350 \% /{ }^{\circ} \mathrm{C}$ \\
\hline Temperature Coefficient $\left(\mathrm{V}_{\mathrm{OC}}\right)$ & $-0.270 \% /{ }^{\circ} \mathrm{C}$ \\
\hline Temperature Coefficient $\left(\mathrm{I}_{\mathrm{SC}}\right)$ & $0.04800 \% /{ }^{\circ} \mathrm{C}$ \\
\hline Module efficiency & $21.2 \%$ \\
\hline
\end{tabular}

The number of modules was estimated based on the available space on the rooftop of each building with the aid of the software tool of area keep outs and accommodation capacity.

The orientation of the PV modules has been determined by comparing the tilt and azimuth using the PVsyst tool, calculating the highest irradiance on the collector plane with minimum losses according to the yearly irradiation yield.

The converters were selected based on a minimum AC/DC ratio of around 1.2, and the shading measurements were calculated using the software provided tools with the assumption of zero shading from one module to another.

Moreover, the software calculated different financial and environmental metrics as part of the technoeconomic evaluation of the final model.

\section{Results And Discussion}

The SEC of the RO plant is around $4.6 \mathrm{kWh} / \mathrm{m}^{3}$, equivalent to $492 \mathrm{~kW}$ as the total required power, Fig. 4. The energy consumption breakdown shows that the high-pressure and booster pumps account for $71.1 \%$ 
of the total SEC, representing around $3.27 \mathrm{kWh} / \mathrm{m}^{3}$, Table (2).

On the other side, the irradiation patterns show that the monthly yield of the global horizontal irradiance is around $2102 \mathrm{kWh} / \mathrm{m}^{2} /$ month with an average of $175 \mathrm{kWh} / \mathrm{m}^{2} /$ month, Fig. 5 .

The best PV orientation resulted in $2253 \mathrm{kWh} / \mathrm{m}^{2}$ annual irradiation yield, with $0 \%$ loss at 1.07 transposition factor was at the tilt angle of $25^{\circ}$ and azimuth of $0^{\circ}$. Moreover, the rooftop area and dimensions feature a space where the modules could be easily oriented with the optimum plane tilts and azimuth.

To facilitate the installation of the modules to use the rooftops' space effectively, pillars were suggested to create a flat surface instead of the building's gable roofs. As a result, the highest area was for the carbon plant rooftop, followed by the RO-1 and RO-3, respectively Table (3).

Table (2)

The SEC breakdown of the BWRO plant (Capacity: $107 \mathrm{~m}^{3} / \mathrm{h}$ )

\begin{tabular}{|lll|}
\hline Process Location & SEC $\left(\mathrm{kWh} / \mathrm{m}^{3}\right)$ & Percentage (\%) \\
\hline Borewell Pump & 0.35 & 7.5 \\
\hline Pretreatment $\left(\mathrm{H}_{2}\right.$ S degasser, MMFs and CFs) & 0.98 & 21.3 \\
\hline RO 1st and 2nd Stage pumps & 3.27 & 71.1 \\
\hline Post-treatment & 0.0012 & 0.026 \\
\hline Total & 4.60 & \\
\hline Load $(\mathrm{kW})$ & 492.225 & \\
\hline
\end{tabular}

\section{Table (3)}

The roof top area of the selected buildings

\begin{tabular}{|lll|}
\hline Building & Roof Top dimension $(\mathrm{m})$ & Area $\left(\mathbf{m}^{2}\right)$ \\
\hline RO-1 Plant & $31 \times 46$ & 1,394 \\
\hline RO-3 Plant & $35 \times 14$ & 487 \\
\hline Carbon Plant & $48 \times 121$ & 5808 \\
\hline Total Area $\left(\mathrm{m}^{2}\right)$ & - & 7,689 \\
\hline
\end{tabular}


The PV modules were chosen from the category of the half-cut cell as it provides a more efficient alternative to the full cell panels. Half-cut cells have more heat and shade resistance and feature higher recovery since they have more strings than the standard modules. Therefore, more output is generated on a cooler surface.

Compared to the polycrystalline panels, the mono-crystalline modules exhibit higher heat tolerance and a longer life span and are more viable for hot-climate regions like GCC.

The panels selected from Longi Solar's LR4 half-cell series manifest an efficiency of around $21.2 \%$ and a maximum peak power of $460 \mathrm{~W}_{\mathrm{p}}$. In addition, the rooftops were segmented, considering the spacing between each row of modules and the keep-out areas. The simulation results showed that around 1,359 modules could be accommodated within the area (Fig. 6), generating DC and AC power of around $625 \mathrm{~kW}$ and $525 \mathrm{~kW}$, respectively, with an overall DC to AC ratio of 1.19 , Table (4).

The string sizing has been set automatically by Helioscope based on the location's weather data, suggesting the optimum size between 13 to 19 , and giving a total range of 97 strings and $3127 \mathrm{~m}$ length.

By analyzing the total of 4,592 operating hours annually, the power production might reach $787 \mathrm{MWh}$ with an overall performance ratio of $79.1 \%$ and a specific yield of $1258 \mathrm{kWh} / \mathrm{kW}_{\mathrm{p}}$.

The highest production levels were obtained during the hottest period from May to August, particularly in June, when the production reaches 104 MWh (Fig. 7).

From an hourly point of view, the power generation varies seasonally depending on the insolation period, especially from May to August, representing the longest diurnal months. For example, from 11 to $12 \mathrm{AM}$, the highest production could be achieved, while the late hours until 5 PM are limited to the months from May to August, Fig. 8.

The system losses results showed the temperature has the highest impact on the performance (6.9\%), followed by the complications of reflection (4.5\%), Fig. 9. Furthermore, the shading report showed that the solar access on the field segments and PV modules is $97.1 \%$.

Since the abundance of solar energy provides a solution to motivate renewable desalination in the area, then the environmental impacts are also significant to address the PV-RO.

The environmental offsets showed that the current model could achieve multiple targets on the projects' lifespan. Helioscope provides environmental metrics based on US EPA greenhouse gas equivalencies to quantify the offsets.

\section{Table (4)}

\section{The PV-RO simulation results}




\begin{tabular}{|llll|}
\hline Building & RO-1 plant & RO-3 plant & Carbon plant \\
\hline Number of modules & 324 & 120 & 915 \\
\hline Total number of modules & 1359 & & 420.9 \\
\hline Power $(\mathrm{kW})$ & 149 & 55.2 & - \\
\hline Total DC power $(\mathrm{kW})$ & 625.1 & - & - \\
\hline Total AC power $(\mathrm{kW})$ & 525.0 & - & - \\
\hline With the load ratio of $\approx 1.20)$ & & & - \\
\hline Annual Production $(\mathrm{MWh})$ & 786.6 & - & $13-19$ \\
\hline Operating hours & 4592 & - & 14 \\
\hline String size & $13-19$ & $13-19$ & - \\
\hline Total number of strings & $97(3127.0 \mathrm{~m})$ & & - \\
\hline Number of inverters & 5 & 2 & - \\
\hline Total number of inverters & 21 & - & - \\
\hline Overall Performance ratio $(\%)$ & 79.1 & - & \\
\hline Total kWh/kW & 1258.3 & - & \\
\hline
\end{tabular}

For instance, the carbon dioxide offset for the project on 25 years is equivalent to 13,076 tons of $\mathrm{CO}_{2}$, while it is equal to $5,600,234$ gallons of consumed gasoline and 30,331 barrels of consumed oil, Table (5).

Financially, the project showed economic viability in terms of the lifetime (25 years), Net Present Value (NPV), Return on Investment (ROI), and Levelized Cost of Energy (LCOE), with a payback period of 8.4 years, Table (6).

Compared to the energy price in Bahrain, which is $0.074 \$ / \mathrm{kWh}$, the LCOE was lower than by $19 \%$, which is a positive indicator of the feasibility of the project.

\section{Table (5)}

The environmental metrics and their equivalent offsets for the PV-RO 


\begin{tabular}{|ll|}
\hline Environmental metrics & Equivalent offset \\
\hline Carbon Dioxide (tons) & 13,076 \\
\hline Waste Recycled Instead of Landfilled (tons) & 4,624 \\
\hline Gasoline Consumed (Liter) & $5,600,234$ \\
\hline Barrels of Oil Consumed (Barrels) & 30,331 \\
\hline Coal Burned (kg) & $6,484,768$ \\
\hline Tree Seedlings Grown for 10 Years (Seedling) & $2,163,889$ \\
\hline
\end{tabular}

Table (6)

The financial metrics of the PV-RO

\begin{tabular}{|ll|}
\hline Financial Metric & \\
\hline Initial Cost & $\$ 625,140$ \\
\hline Total value of energy & $\$ 1,689,519$ \\
\hline Lifetime NPV & $\$$ \\
\hline Return on Investment (ROI) & $268,609.17$ \\
\hline Payback period & $265 \%$ \\
\hline Levelized Cost of Energy (LCOE) & $\$ .4$ years \\
\hline
\end{tabular}

\section{Conclusion}

The desalination industry in the GCC region is associated with very high energy consumption and correspondingly causes multiple environmental impacts due to the interdependence on fossil fuels. Nevertheless, the region enjoys an abundant solar energy resource. Therefore, renewable energy-driven desalination, particularly the PV-ROs, represents an appealing solution to reduce the carbon footprints of the industry.

To assess the appropriate PV design, this work investigates an industrial BWRO with SEC of $4.6 \mathrm{kWh} / \mathrm{m}^{3}$ and $492 \mathrm{~kW}$ total energy demand.

The rooftops of three buildings, including the plant itself, have been used in the simulation, featuring a total surface area of 7,689 $\mathrm{m}^{2}$. The model showed that 1,359 PV $\left(460 \mathrm{~W}_{\mathrm{p}}\right)$ modules could be accommodated to generate $625 \mathrm{~kW} \mathrm{DC}$ and $525 \mathrm{AC}$ power, respectively. 
The overall performance ratio was $79 \%(A C / D C$ ratio $\approx 1.2)$ combined with 21 inverters, each with $25 \mathrm{~kW}$ capacity. The ratio of the obtained energy to the maximum power of the PV module was $1258 \mathrm{kWh} / \mathrm{kW}_{\mathrm{p}}$, exhibiting a very high specific yield.

The environmental metrics over the 25 years life span showed that offset of carbon dioxide emissions could reach 13,076 tons compared to conventional fossil fuel.

Financially, the NPV showed a positive value of $\$ 268,609$ as an indicator of viability, and so the LCOE $(0.06 \$ / \mathrm{kWh})$ is lower than the current energy unit price $(0.074 \$ / \mathrm{kWh})$.

Further work is recommended for the thermal modeling of all buildings to estimate the cooling and heating rates that might influence the PV performance.

Moreover, an in-depth financial study is required to stand on the financial metrics of the model, considering the up-to-date inflation and interest rates as well as the operational and maintenance costs.

\section{Abbreviations}

RO: Reverse Osmosis

BWRO: Brackish Water Reverse Osmosis

SEC: Specific Energy Consumption $\left(\mathrm{kWh} / \mathrm{m}^{3}\right)$

PV: Photovoltaic

TDS: Total Dissolved Solids

GCC: Gulf Cooperation Council

AC: Alternating Current

DC: Direct Current

ROI: Return on Investment

LCOE: Levelized Cost of Energy

$\mathrm{CO}_{2}$ : carbon dioxide

$\mathrm{H}_{2} \mathrm{~S}$ : hydrogen sulfide

\section{Units}

M: mega $\left(10^{6}\right)$ 
k: kilo $\left(10^{3}\right)$

W: Watt

$\mathrm{W}_{\mathrm{p}}$ : maximum power (Watt)

h: hour

m: meter

mg: milligram

I: Liter

\section{Declarations}

Data Availability: The datasets used and/or analysed during the current study available from the corresponding author on reasonable request.

\section{References}

1. Abdmouleh, Z., Alammari, R. A. M., \& Gastli, A. (2015). Recommendations on renewable energy policies for the GCC countries. Renewable and Sustainable Energy Reviews, 50, 1181-1191. https://doi.org/10.1016/j.rser.2015.05.057

2. Ahmed, F. E., Hashaikeh, R., \& Hilal, N. (2019). Solar powered desalination - Technology, energy and future outlook. In Desalination (Vol. 453, Issue November 2018, pp. 54-76). Elsevier. https://doi.org/10.1016/j.desal.2018.12.002

3. Al-Karaghouli, A., \& Kazmerski, L. L. (2013). Energy consumption and water production cost of conventional and renewable-energy-powered desalination processes. Renewable and Sustainable Energy Reviews, 24, 343-356. https://doi.org/10.1016/j.rser.2012.12.064

4. Al-Qahtani, H. (1996). Feasibility of utilizing solar energy to power reverse osmosis domestic unit to desalinate water in the state of Bahrain. Renewable Energy, 8(1-4), 500-504. https://doi.org/https://doi.org/10.1016/0960-1481(96)88907-5

5. Al-Zubari, W., Al-Turbak, A., Zahid, W., Al-Ruwis, K., Al-Tkhais, A., Al-Muataz, I., Abdelwahab, A., Murad, A., Al-Harbi, M., \& Al-Sulaymani, Z. (2017). An overview of the GCC Unified Water Strategy (20162035). Desalination and Water Treatment, $81,1-18$. https://doi.org/10.5004/dwt.2017.20864

6. Alnaser, W., \& Alnaser, N. W. (2009). Solar and wind energy potential in GCC countries and some related projects. Journal of Renewable and Sustainable Energy, 1. https://doi.org/10.1063/1.3076058

7. Alnaser, W. E., \& Alnaser, N. W. (2011). The status of renewable energy in the GCC countries. Renewable and Sustainable Energy Reviews, 15(6), 3074-3098. 
https://doi.org/10.1016/j.rser.2011.03.021

8. Alsheghri, A., Sharief, S. A., Rabbani, S., \& Aitzhan, N. Z. (2015). Design and Cost Analysis of a Solar Photovoltaic Powered Reverse Osmosis Plant for Masdar Institute. Energy Procedia, 75. https://doi.org/10.1016/j.egypro.2015.07.365

9. Atalay, Y., Kalfagianni, A., \& Pattberg, P. (2017). Renewable energy support mechanisms in the Gulf Cooperation Council states: Analyzing the feasibility of feed-in tari ff $\mathrm{s}$ and auction mechanisms. Renewable and Sustainable Energy Reviews, 72(January), 723-733. https://doi.org/10.1016/j.rser.2017.01.103

10. Banat, F., Qiblawey, H., \& Al-nasser, Q. (2012). Design and Operation of Small-Scale PhotovoltaicDriven Reverse Osmosis (PV-RO) Desalination Plant for Water Supply in Rural Areas. 2012(October), 31-36.

11. Dawoud, M. A. (2005). The role of desalination in augmentation of water supply in GCC countries. Desalination, 186(1-3), 187-198. https://doi.org/10.1016/j.desal.2005.03.094

12. Elmaadawy, K., Kotb, K. M., Elkadeem, M. R., \& Sharshir, S. W. (2020). Optimal sizing and technoenviro-economic feasibility assessment of large-scale reverse osmosis desalination powered with hybrid renewable energy sources. 224(June). https://doi.org/10.1016/j.enconman.2020.113377

13. Freire-Gormaly, M., \& Bilton, A. M. (2018). Experimental quantification of the effect of intermittent operation on membrane performance of solar powered reverse osmosis desalination systems. Desalination, 435(September 2017), 188-197. https://doi.org/10.1016/j.desal.2017.09.013

14. Freire-Gormaly, M., \& Bilton, A. M. (2019). Design of photovoltaic powered reverse osmosis desalination systems considering membrane fouling caused by intermittent operation. Renewable Energy, 135, 108-121. https://doi.org/10.1016/j.renene.2018.11.065

15. Ghaffour, N., Bundschuh, J., Mahmoudi, H., \& Goosen, M. F. A. (2015). Renewable energy-driven desalination technologies: A comprehensive review on challenges and potential applications of integrated systems. In Desalination (Vol. 356). https://doi.org/10.1016/j.desal.2014.10.024

16. Karavas, C. S., Arvanitis, K. G., \& Papadakis, G. (2019). Optimal technical and economic configuration of photovoltaic powered reverse osmosis desalination systems operating in autonomous mode. Desalination, 466(April), 97-106. https://doi.org/10.1016/j.desal.2019.05.007

17. Li, S., Cai, Y., Schäfer, A. I., \& Richards, B. S. (2019). Renewable energy powered membrane technology: A review of the reliability of photovoltaic-powered membrane system components for brackish water desalination. Applied Energy, 253(July), 113524.

https://doi.org/10.1016/j.apenergy.2019.113524

18. Lindemann, J. H. (2004). Wind and solar powered seawater desalination Applied solutions for the Mediterranean, the Middle East and the Gulf Countries. 168, 73-80.

19. Mahmoudi, H., Ghaffour, N., Goosen, M. T. F. A., \& Bundschuh, J. (2017). Renewable energy technologies for water desalination. In Renewable Energy Technologies for Water Desalination. https://doi.org/10.1201/9781315643915 
20. Mito, M. T., Ma, X., Albuflasa, H., \& Davies, P. A. (2019). Reverse osmosis (RO) membrane desalination driven by wind and solar photovoltaic (PV) energy: State of the art and challenges for large-scale implementation. Renewable and Sustainable Energy Reviews, 112(May), 669-685. https://doi.org/10.1016/j.rser.2019.06.008

21. Munawwar, S., \& Ghedira, H. (2014). A review of renewable energy and solar industry growth in the GCC region. Energy Procedia, 57, 3191-3202. https://doi.org/10.1016/j.egypro.2015.06.069

22. Pirani, S. I., \& Arafat, H. A. (2016). Interplay of food security, agriculture and tourism within GCC countries. Global Food Security, 9(2016), 1-9. https://doi.org/10.1016/j.gfs.2016.05.002

23. Rahimi, B., Shirvani, H., Alamolhoda, A. A., Farhadi, F., \& Karimi, M. (2021). A feasibility study of solarpowered reverse osmosis processes. Desalination, 500(June 2020), 114885.

https://doi.org/10.1016/j.desal.2020.114885

24. Saif, O. (2012). The Future Outlook of Desalination in the Gulf:Challenges \& Opportunities faced by Qatar \& the UAE. Report. 63 pp. http://inweh.unu.edu/wp-content/uploads/2013/11/The-FutureOutlook-of-Desalination-in-the-Gulf.pdf

25. Saif, O., Mezher, T., \& Arafat, H. A. (2014). Water security in the GCC countries: challenges and opportunities. Journal of Environmental Studies and Sciences, 4(4), 329-346. https://doi.org/10.1007/s13412-014-0178-8

26. Shatat, M., Worall, M., \& Riffat, S. (2013). Opportunities for solar water desalination worldwide: Review. Sustainable Cities and Society, 9, 67-80. https://doi.org/10.1016/j.scs.2013.03.004

27. Shomar, B., \& Hawari, J. (2017). Desalinated drinking water in the GCC countries - The need to address consumer perceptions. Environmental Research, 158(June), 203-211. https://doi.org/10.1016/j.envres.2017.06.018

28. Zarzo, D., \& Prats, D. (2018). Desalination and energy consumption. What can we expect in the near future? Desalination, 427(August 2017), 1-9. https://doi.org/10.1016/j.desal.2017.10.046

\section{Figures}




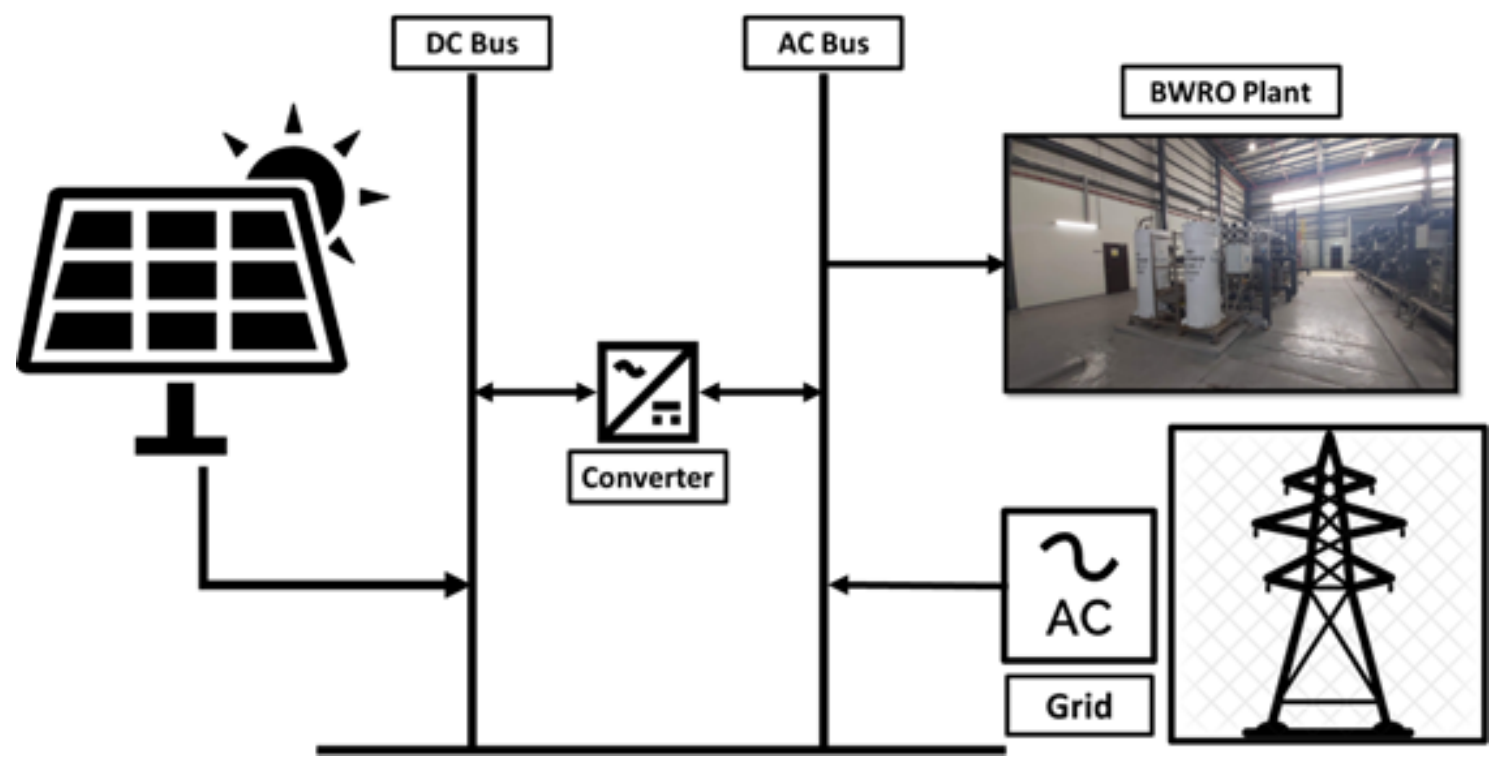

Figure 1

Schematic of hybrid grid-tied solar PV/inverter power system

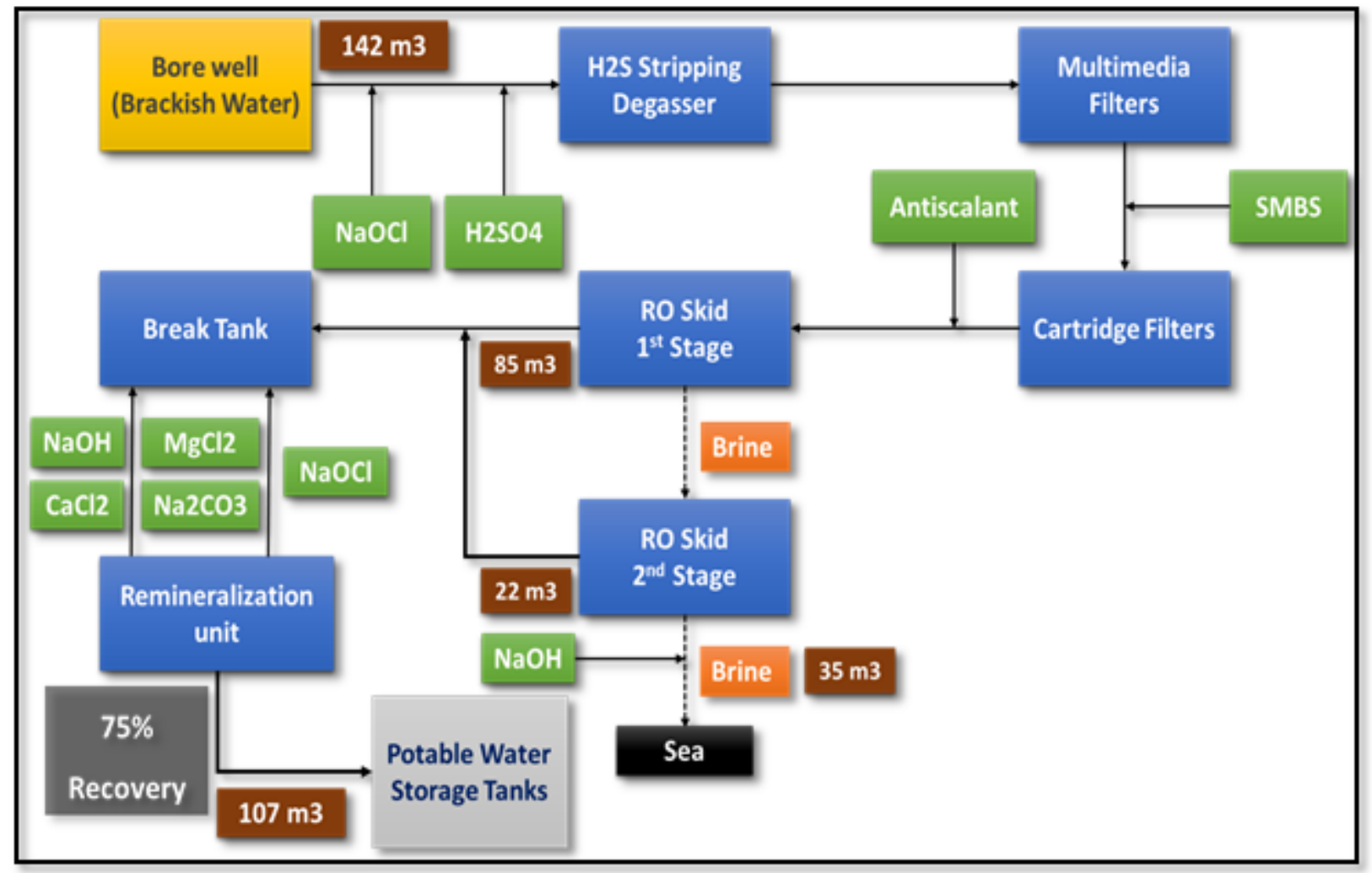

Figure 2

The schematic diagram of the BWRO plant 


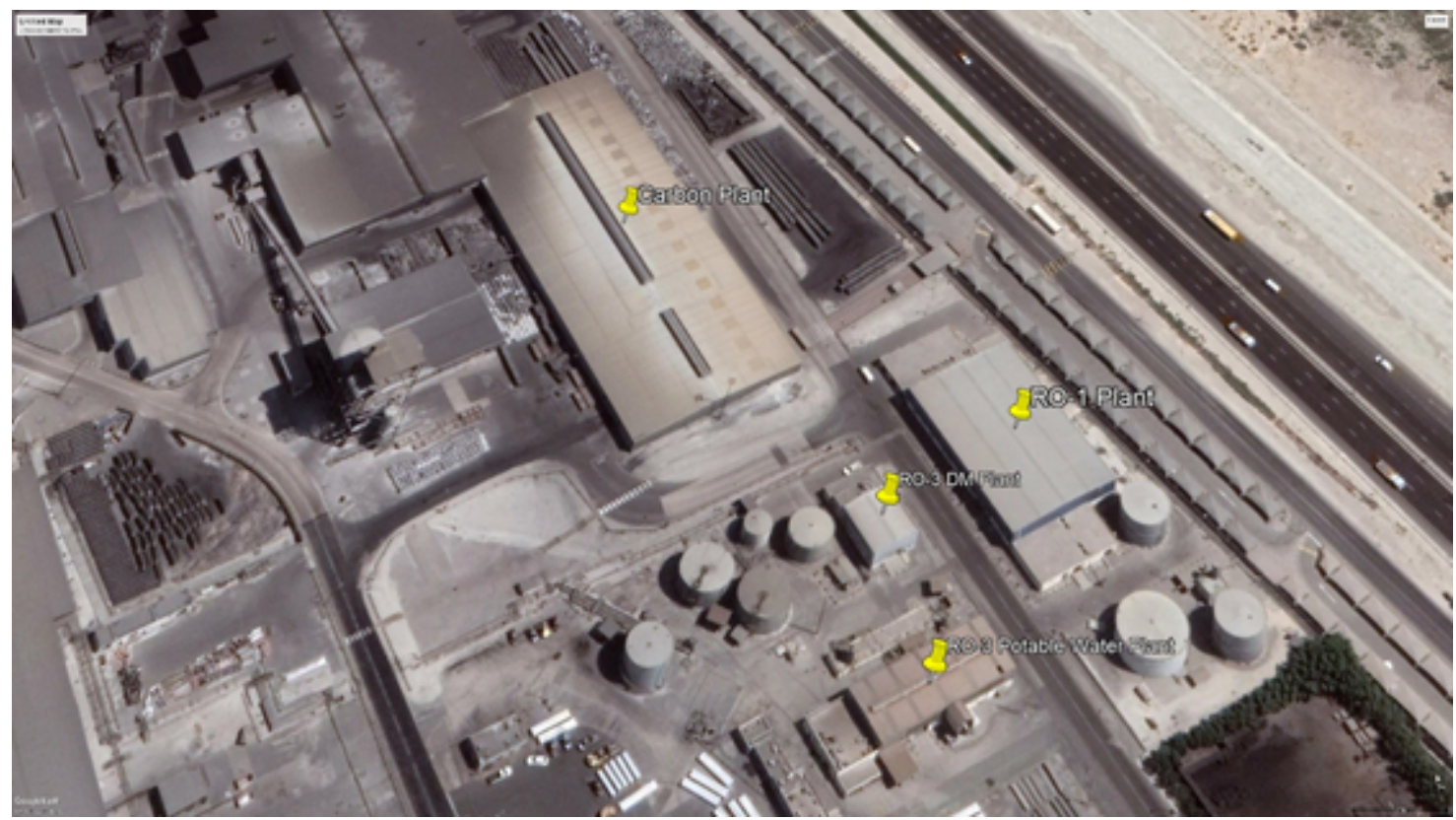

Figure 3

The buildings where the PV arrays would be installed on their rooftops

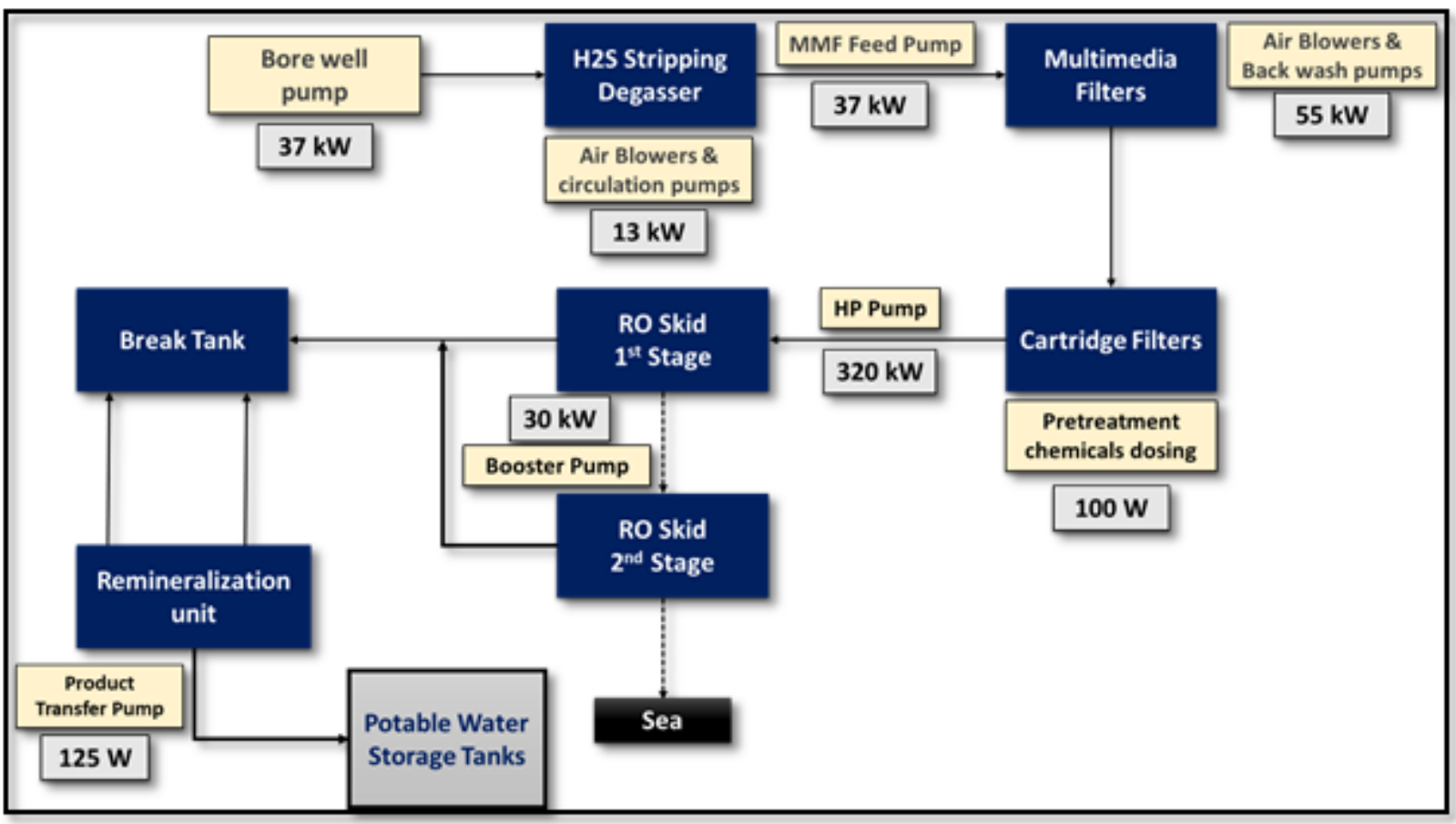

Figure 4

Energy inventory results 


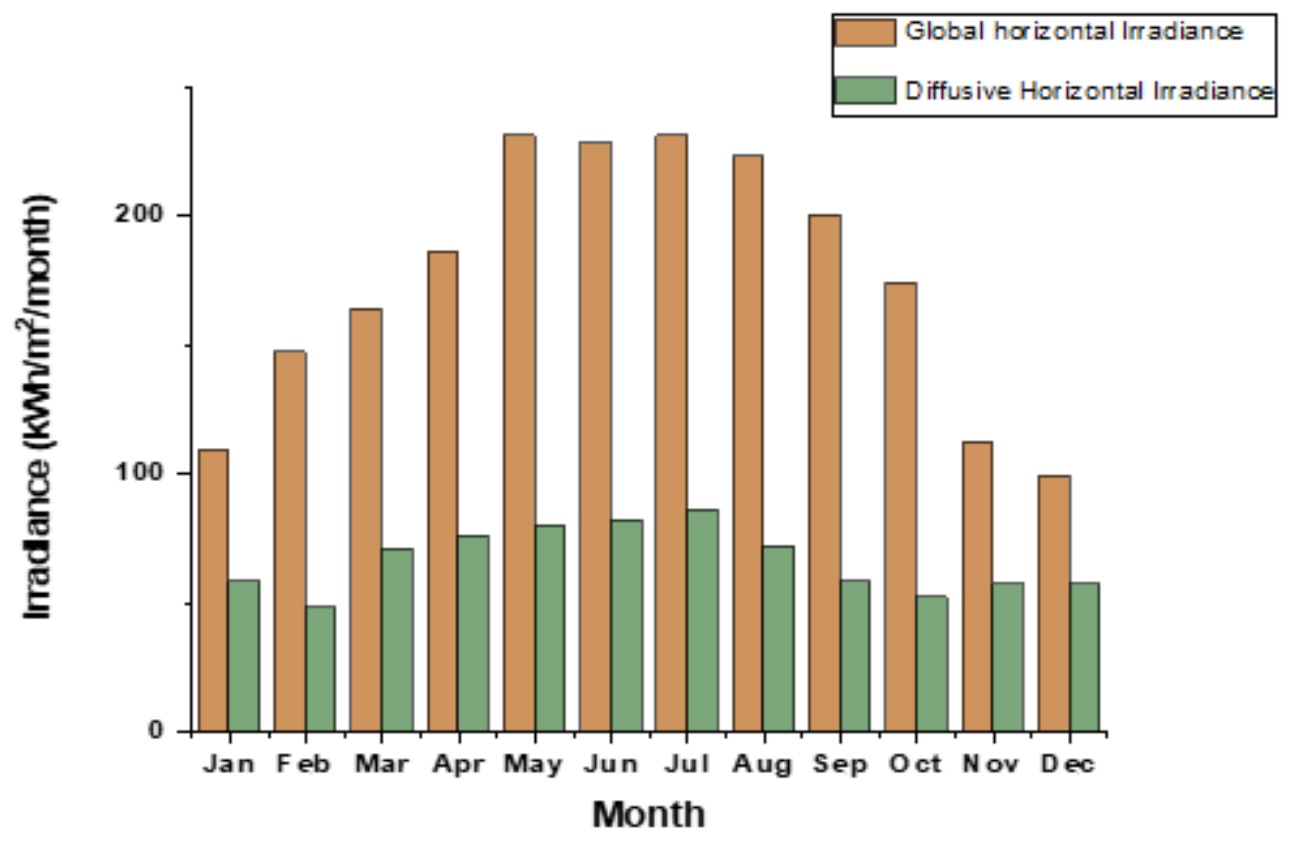

Figure 5

Global and diffusive horizontal irradiance data 


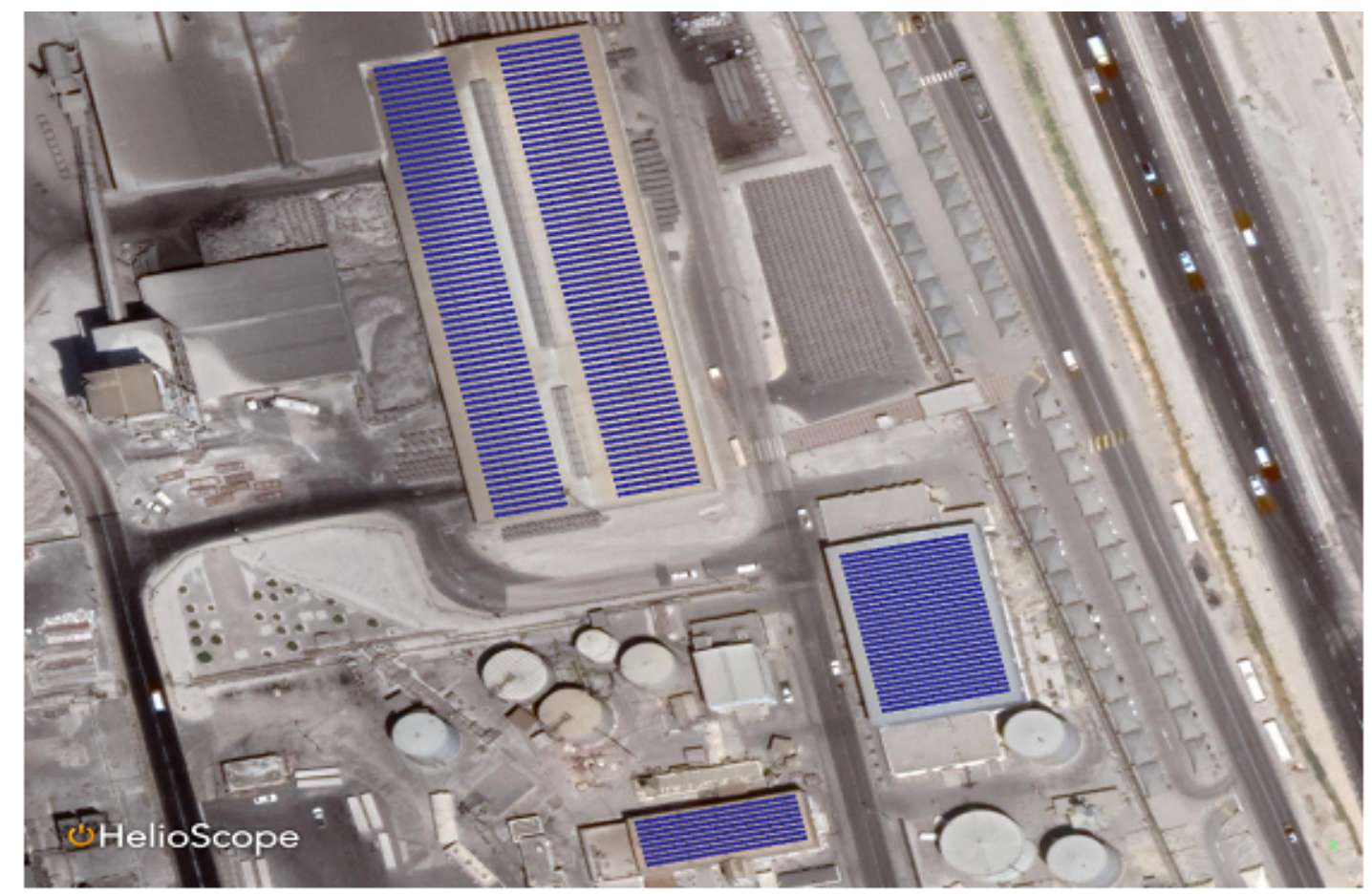

(a)

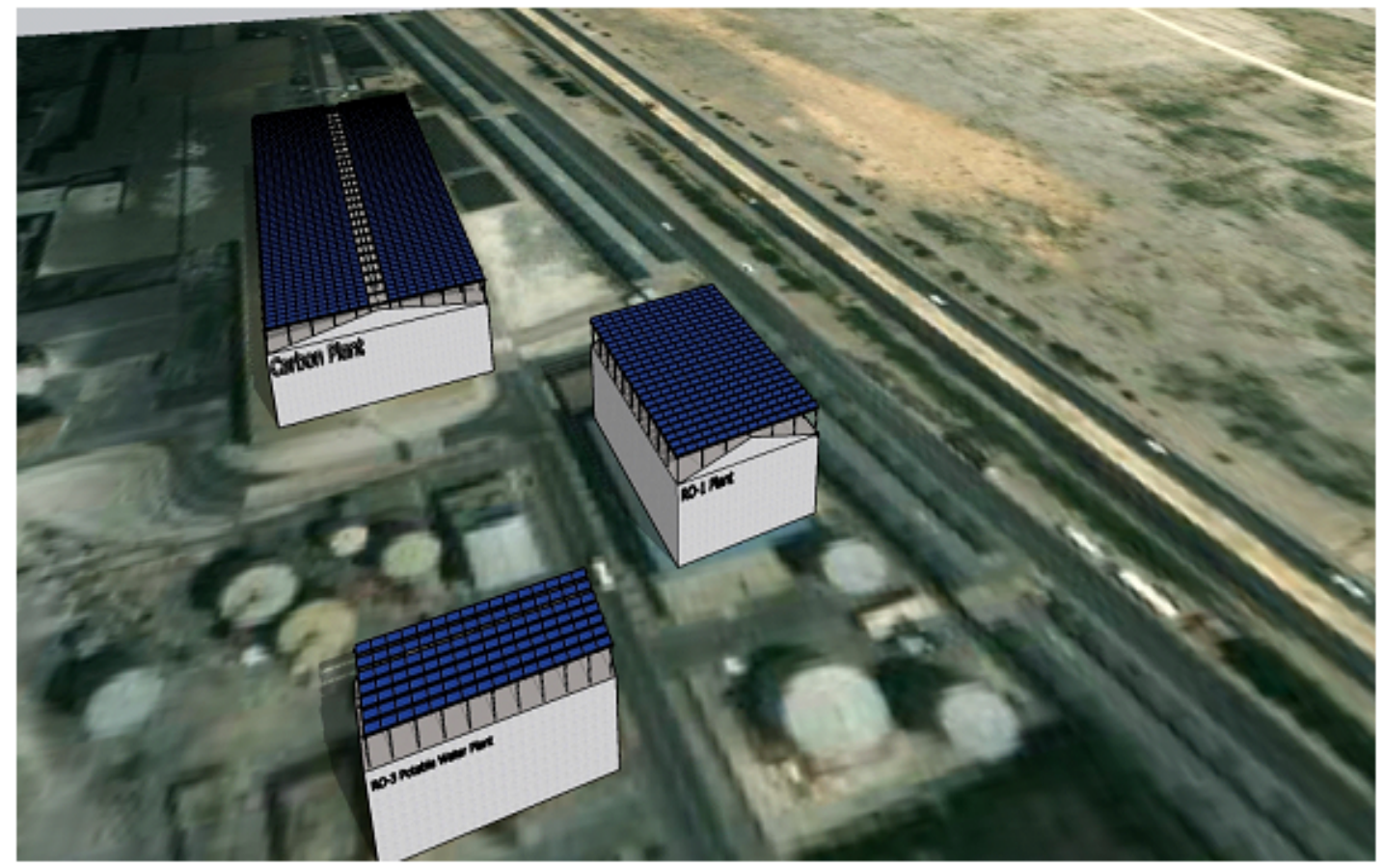

(b)

Figure 6

The arrangements of the PV modules (a) Helioscope 2D model (b) 3D model with pillars on the rooftops 


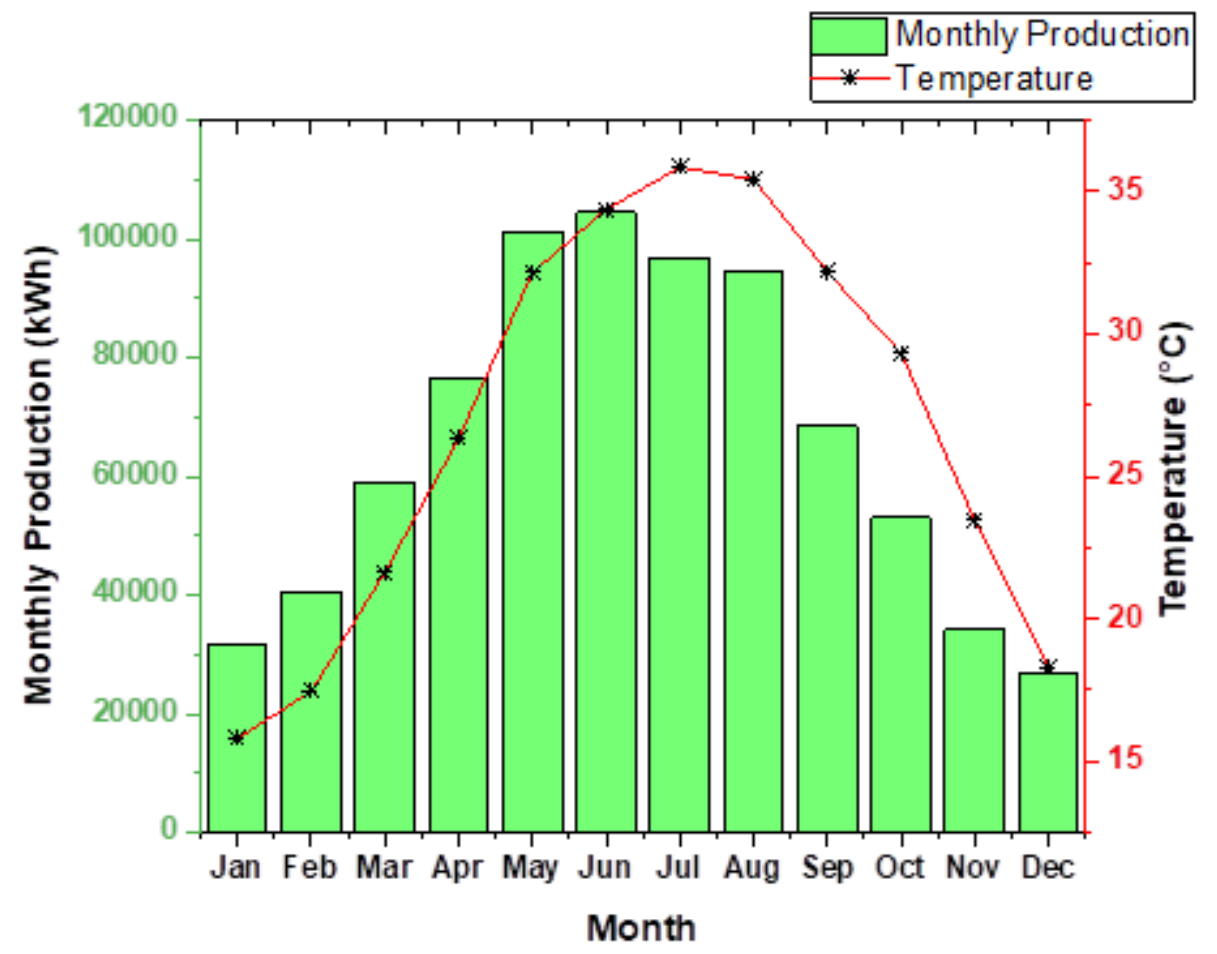

Figure 7

Monthly production (kWh) and temperature $\left({ }^{\circ} \mathrm{C}\right)$ 


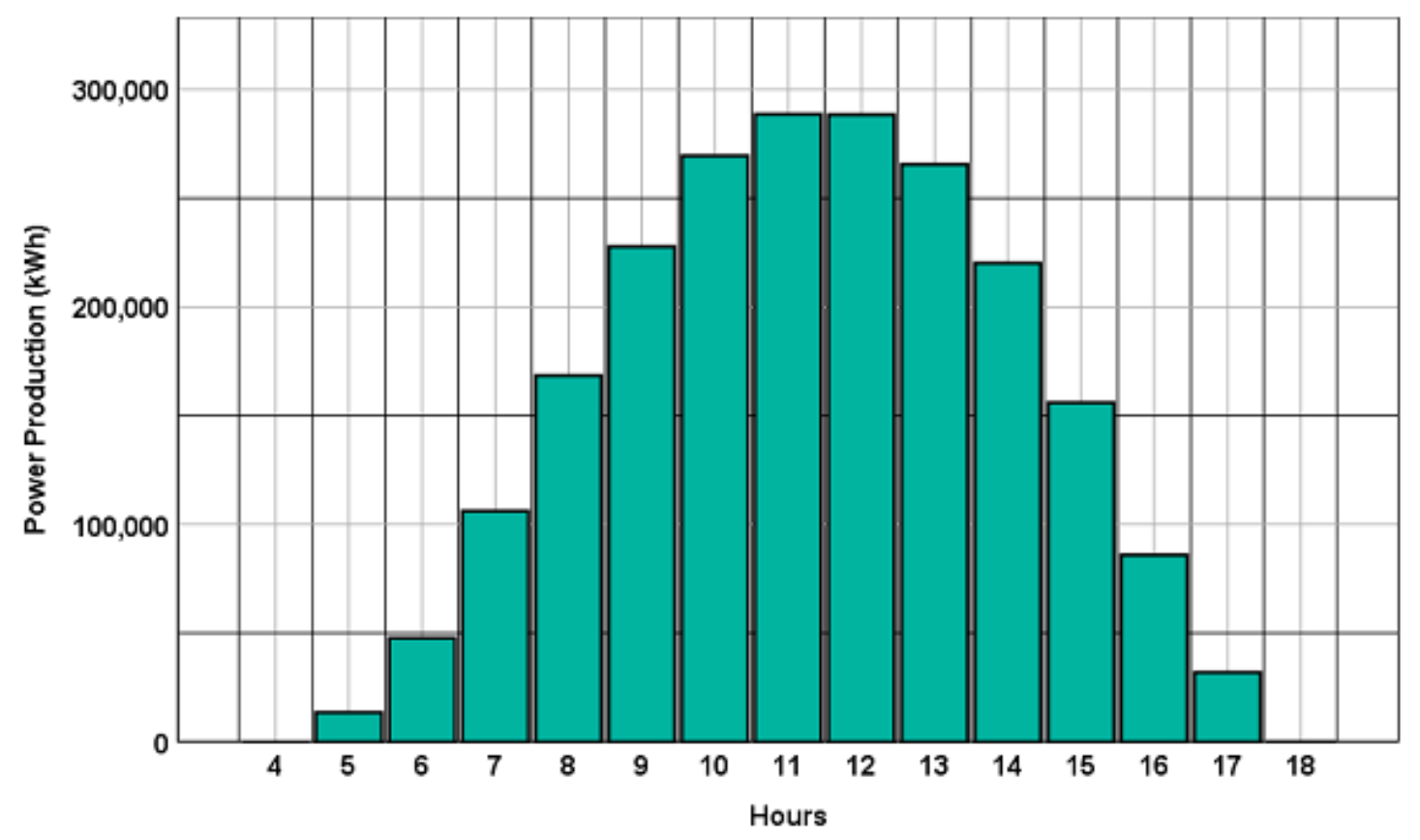

(a)

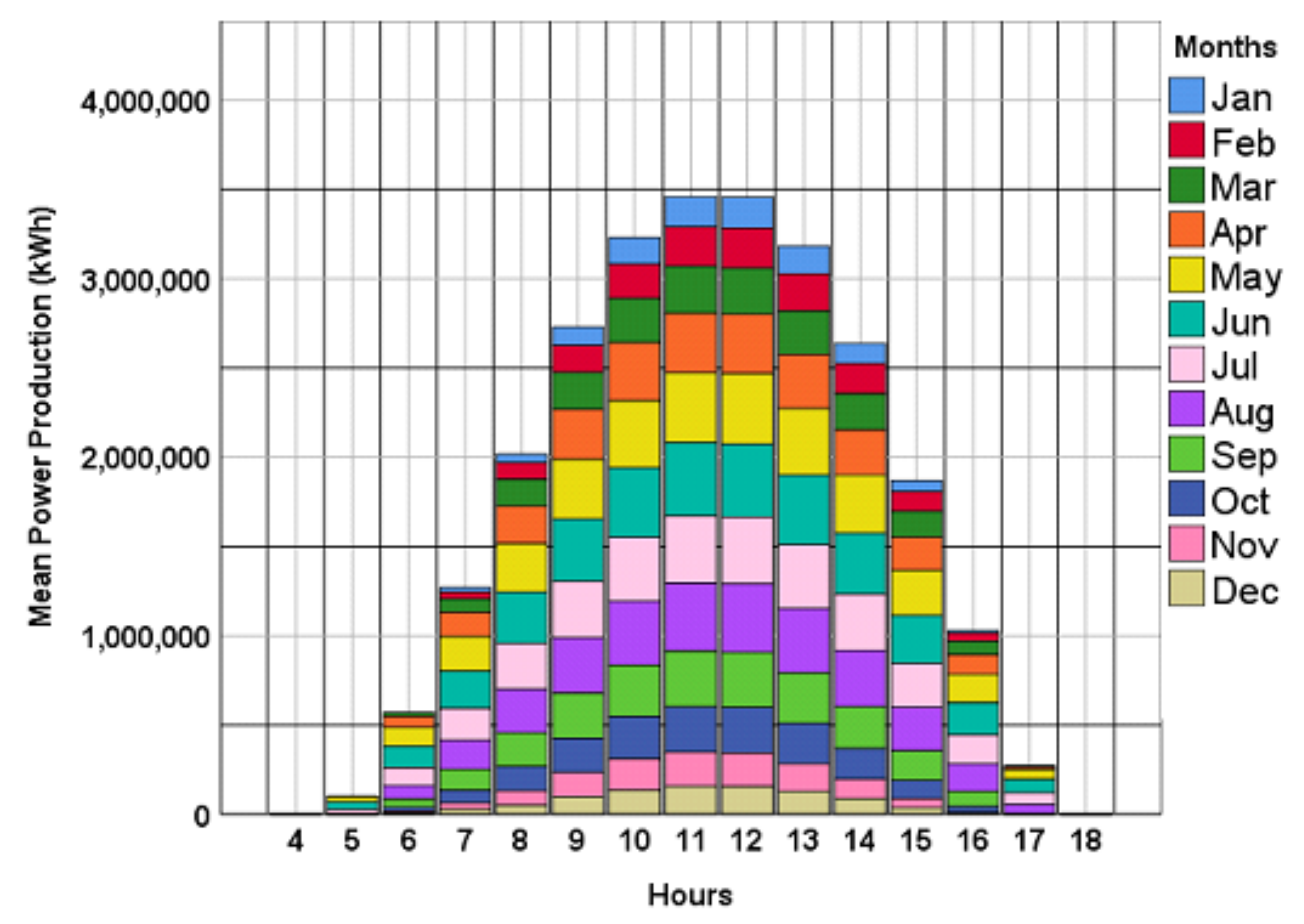

(b)

Figure 8

The hourly production patterns

(a) The average of hourly production (b) The average of hourly production every month 


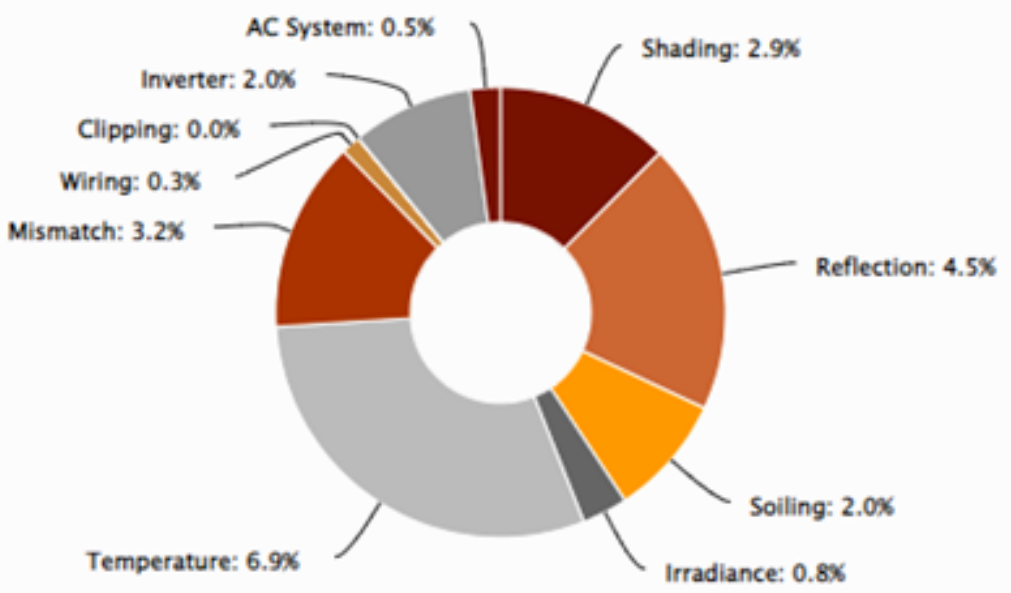

Figure 9

The system losses contribution by percentages

\section{Supplementary Files}

This is a list of supplementary files associated with this preprint. Click to download.

- Supp.InfoDesignPaper.docx 